\title{
The quality of procedures to assess and credit prior learning: Implications for design.
}

Citation for published version (APA):

Joosten-ten Brinke, D., Sluijsmans, D., Brand-Gruwel, S., \& Jochems, W. (2008). The quality of procedures to assess and credit prior learning: Implications for design. Educational Research Review, 3(1), 51-65.

https://doi.org/10.1016/j.edurev.2007.08.001

DOI:

10.1016/j.edurev.2007.08.001

Document status and date:

Published: 01/01/2008

Document Version:

Peer reviewed version

Please check the document version of this publication:

- A submitted manuscript is the version of the article upon submission and before peer-review. There can be important differences between the submitted version and the official published version of record. People interested in the research are advised to contact the author for the final version of the publication, or visit the DOI to the publisher's website.

- The final author version and the galley proof are versions of the publication after peer review.

- The final published version features the final layout of the paper including the volume, issue and page numbers.

Link to publication

\section{General rights}

Copyright and moral rights for the publications made accessible in the public portal are retained by the authors and/or other copyright owners and it is a condition of accessing publications that users recognise and abide by the legal requirements associated with these rights.

- Users may download and print one copy of any publication from the public portal for the purpose of private study or research.

- You may not further distribute the material or use it for any profit-making activity or commercial gain

- You may freely distribute the URL identifying the publication in the public portal.

If the publication is distributed under the terms of Article 25fa of the Dutch Copyright Act, indicated by the "Taverne" license above, please follow below link for the End User Agreement:

https://www.ou.nl/taverne-agreement

Take down policy

If you believe that this document breaches copyright please contact us at:

pure-support@ou.nl

providing details and we will investigate your claim.

Downloaded from https://research.ou.nl/ on date: 26 Apr. 2023 
Running head: QUALITY OF PROCEDURES TO ASSESS PRIOR LEARNING

This is a pre-print of the article that was published as

Joosten-ten Brinke, D., Sluijsmans, D. M. A., Brand-Gruwel, S., \& Jochems, W. M. G. (2008). The quality of procedures to assess and credit prior learning: Implications for design.

Educational Research Review, 3, 51-65. doi:10.1016/j.edurev.2007.08.001.

Copyright Elsevier, available online at

http://www.elsevier.com/wps/find/journaldescription.cws_home/706817/description\#description

The Quality of Procedures to Assess and Credit Prior Learning: Implications for Design

D. Joosten-ten Brinke' ${ }^{1}$, D.M.A. Sluijsmans ${ }^{1}$, S. Brand-Gruwel' ${ }^{1}$, W.M.G. Jochems ${ }^{2}$

${ }^{1}$ Open University of the Netherlands, PO Box 2960, 6401 DL Heerlen

${ }^{2}$ Open University of the Netherlands and Eindhoven School of Education, PO Box 513, $5600 \mathrm{MB}$

Eindhoven

Correspondence concerning this article should be addressed to Desirée Joosten- ten Brinke,

Open University of the Netherlands, Educational Technology Expertise Center,

P.O. Box 2960, 6401 DL Heerlen, The Netherlands, voice: ++31-45-5762758, fax:

$++31-45-5762800$,

e-mail: desiree.joosten-tenbrinke@,ou.nl 
Quality of Procedures to Assess Prior learning 2

\begin{abstract}
The ever-changing requirements of working life require individuals to develop their competencies throughout their life cycle. This lifelong learning paradigm requires a renewed vision concerning assessment in which, besides formal learning, informal and non-formal learning experiences are also recognized. To support this lifelong learning paradigm, procedures have been developed worldwide to assess and credit prior learning experiences (APL). While research on APL stresses the importance of a high-quality standard, so far the literature has applied only a psychometric quality framework.

However, from the perspective of APL, where, besides prior knowledge and skills, competencies need to be measured, it is more appropriate to use a combination of the psychometric and edumetric quality criteria. This article will analyze and describe the relationship between quality criteria and the characteristics of APL. The results have revealed that quality criteria based on both are fundamental for APL, but that some criteria are more recognized than are others. Based on this analysis, design guidelines for APL have been formulated.
\end{abstract}


The Quality of Procedures to Assess and Credit Prior learning: Implications for Design

This article describes the procedures for assessing and crediting prior learning (APL) in relation to the quality criteria for assessment from the perspective that these procedures are assessment programs in which all kinds of prior learning can be assessed. We will first discuss the context of these procedures as well as the literature on assessment quality. This will be followed by the results of the review of the literature on the characteristics of APL and the implications for design in relation to the quality criteria. Finally, a conclusion and directions for further research will be formulated.

Lifelong learning requires a belief in the value of learning in all phases of life (Koper, Rusman, \& Sloep, 2005). Consequently, learners should be enabled to enter educational programs at various levels adjusted to their existing competence profiles in order to acquire competences at their own pace by selecting appropriate learning tasks and applying for assessment when ready (Cretchley \& Castle, 2001). In such a learning environment, lifelong learners will plan their own learning path in order to make flexible choices in their personal development and to reach desired standards of competence. When entering a new educational program, most learners have, to a certain extent, already acquired competencies in different learning settings. Three types of learning foster this acquisition of competences (The Calibre group of Companies, 2003). Formal learning, based on the achievement of competences with related certificates, is intentional, which means that learning is a goal rather than an incidental outcome. Non-formal learning, similar to formal learning, is characterized by an intentional learning objective within a structured context, such as schools or classes, but there is no legally or socially recorded certification. Examples of this are workplace-based training and non-credit courses such as a home course on typing. Informal learning, or non-sponsored learning (Blinkhorn, 1999), is not intentional, not structured and does not lead to certification. Learning is undertaken on one's own initiative, individually or collectively, without externally imposed criteria or the presence of an institutionally authorized instructor (Livingstone, 2000). Examples of this are volunteer activities, life experiences, self-instruction, family responses and hobbies.

Up until a few decades ago, educational institutions recognized only formal learning. Nowadays educational institutions also endorse the value of informal and non-formal learning by enrolling learners in educational programs at various levels. The development of assessment procedures that allow learners to enter educational programs based on their prior informal and non-formal learning is 
an important step towards lifelong learning (Evans, 2003). In general, these assessment procedures have seven main characteristics: (1) different types of learning are recognized ([Evans, 2003] and [Nyatanga, 1993]); (2) the procedures have a clear structure and time schedule ([Human Resource Development, 1995] and [Nyatanga, 1993]); (3) the outcome of each procedure can differ (credit points, exemptions, study plan) (Challis, 1996); (4) the procedures are beneficial for the learner, the educational institution and the community (Aarts et al., 2003); (5) a combination of methods (simulations, knowledge tests, performance assessments, interviews) is used to provide evidence of prior learning (Fjortoft \& Zgarrick, 2001); (6) the procedures require a high level of responsibility from learners and a sufficient level of support (Donoghue, Pelletier, Adams, \& Duffield, 2002); (7) the procedures are time-consuming (Bélanger \& Mount, 1998; The Calibre group of Companies, 2003; Thomas, Broekhoven, \& Frietman, 2000; Wheelahan, Miller, \& Newton, 2002). In this article, we focus on these procedures in relation to their opportunity to allow learners to enter formal educational programs based on all kinds of prior learning, although APL also is used outside the context of educational programs, for example in workplaces. Many terms are available for these kind of procedures, but because we analyzed them with the accent on assessment, we will use the English term Assessment of Prior learning (henceforth indicated as APL).

Research on APL stresses the importance of a high-quality standard for assessing and crediting prior learning (Bateman \& Knight, 2003; [Duvekot, 2001], [Freed, 2006] and [Ministry of Economic Affairs, 2000]; Nyatanga, Forman \& Fox, 1998; The Calibre group of Companies, 2003; [Thomas et al., 2000] and [Vanhoren, 2002]). These quality standards are mainly based on psychometric quality criteria like reliability and validity. However, for APL - a procedure to which the learners' competency level is central - a definition of quality is required that is in line with current views on competency assessment. This view supports a combination of assessment methods to assess competencies. According to Duvekot (2001) and the Scottish Qualifications Authority (1997), the traditional psychometric criteria should be expanded for APL by adding criteria that are in line with the goals of APL. Because APL uses combinations of assessments (mentioned in characteristic five), it is more appropriate to evaluate such assessment programs using both psychometric and edumetric criteria ([Baartman et al., 2006] and [Baartman et al., 2007]). The difference between psychometric and edumetric criteria is that the psychometric criteria focus on measuring the differences between learners, while edumetric criteria 
focus on measuring within-learner growth. The psychometric criteria are more directed at quantitative establishment of stable characteristics. Standardization is therefore essential. The edumetric criteria should do more justice to the characteristic of competency assessment, by emphasizing the flexibility and authenticity of assessments and the integration of assessments.

In this article, we will analyze the literature on APL to gain insight into the quality of these procedures and to develop guidelines for optimizing this quality. We will use the quality framework of Baartman et al. (2006), who built their framework on the work of other assessment researchers (see e.g., Benett, 1993; Dierick \& Dochy, 2001; Gulikers, Bastiaens, \& Kirschner, 2004; Hambleton, 1996; Linn, Baker, \& Dunbar, 1991; Sluijsmans, Straetmans, \& Van Merriënboer, submitted for publication). This framework includes 12 quality criteria, briefly described in Table 1.

Insert Table 1 about here

In their framework, Baartman et al. (2006) distinguish four levels. Fitness for purpose, the first level, is the basis for the development of all competency assessment programs. The next level of assessment quality consists of the criteria transparency, acceptability, reproducibility of decisions, and comparability. These four criteria are more commonly used in actual practice for the evaluation of assessments. According to Baartman, the third level consists of the quality criteria of fairness, cognitive complexity, fitness for self-assessment, meaningfulness and authenticity. In general, these criteria are newer and are expected to be less commonly used in practice than are transparency, acceptability, reproducibility of decisions and comparability. The second level tends to be a prerequisite for the third level of criteria. Finally, the criteria of educational consequences and costs and efficiency are conditional criteria. If an assessment is negatively evaluated based on one of these conditional criteria, implementation is definitely not advised.

To design APL procedures in higher education that meet the criteria of the quality framework outlined in Table 1, our main question is: How are the characteristics of APL elaborated in the literature, and what is the relationship between APL and the quality framework for competency assessment? Based on this analysis, design guidelines for APL can be formulated.

\section{Method}

In order to answer the research question, a search of the literature was conducted using the databases of the Academic Search Elite, Psychinfo, Educational Resources Information Center 
(ERIC), Psychlit and Electronic Journal Service. This search was restricted to the period 1990-2007, using the following keywords: "prior learning," "assessment," "recognition" and "accreditation." This search resulted in 122 articles. The abstracts of these articles were analyzed using the seven characteristics of APL: (1) type of learning, (2) structure of APL, (3) possible outcomes of APL, (4) benefits, (5) methods, (6) learner support and (7) time investment. An article was selected when information was found on at least one of these characteristics. This selection resulted in 42 documents. Through the so-called snowball method, the references in these articles were checked for other relevant studies, resulting in a total of 59 articles. These studies were subsequently analyzed using these characteristics as indicators for the quality framework of Baartman et al. (2006). Design guidelines were formulated based on this analysis. Only a small minority of the articles was empirical, the majority of them were descriptive.

Results

In the following, the literature on APL is specified for each characteristic. Subsequently, the relationship to the quality criteria can be described.

Type of learning

Insert Table 2 about here

Table 2 gives an overview of the used terms and abbreviations for procedures to assess and credit prior learning and the type of learning that is assigned to that term by different authors.

Although there is a large variety in the terms to define APL, there is not a one-to-one relation between term and type of learning. For example, if we look up the second column for 'skills and knowledge' we see that Bélanger and Mount (1998) use that type of learning in combination with PLAR and Day (2001b), Evans (2003), Fjortoft and Zgarrick (2001) and Human Resource Development (1995) use the same type of learning with PLA. The reason for this is that the terms and abbreviations used originate in different countries (Clarke \& Warr, 1997; [Day, 2001a] and [Nyatanga, 1993]) and there are country-specific differences (Bélanger \& Mount, 1998). In Scotland and France, for example, it is used to bridge the gap between acquired learning and needed or desired learning, while in Canada and the United States, it is used to credit prior learning as part of a final academic credential. The distinction between formal, non-formal and informal learning is clearly expressed in "Accreditation of Prior Experiential Learning" (APEL), but this distinction is not clear for "Prior learning Assessment" 
(PLA), "Prior learning Assessment and Recognition" (PLAR), "Recognition of Prior learning" (RPL), "Accreditation of Prior learning" (APL), "Assessment of Prior learning" (APL) and Valuation and Validation of Prior learning (VPL). These terms differ as to the type of prior learning in terms of competence or skills and knowledge. "Recognition of Acquired Competences" (in Dutch: EVC, Erkennen van Verworven Competenties) emphasize on competence assessment. Bateman and Knight (2003) use also the concept Recognition of Current Competency to stress that these competences must be of current interest and they use "Skill Recognition" (SR) if the emphasis is on skills. Although Andersson and Fejes (2005) use the term RPL in their article, they prefer to use the term "Validation", based on the French term "Validation des Acquis de l'Expérience" (VAE). Colardyn and Bjørnavold (2004) define validation as the process of identifying, assessing and recognizing a wider range of skills and competences that people develop throughout their lives and in different contexts.

As shown in Table 2, authors use the same terms and their abbreviations in different ways. Day (2001a) and Aarts et al. (2003) both use PLAR, but Day uses a broader view on the subject of the prior learning than do Aarts et al., in the sense that the definition of Aarts et al. is limited to learning acquired outside known public educational institutions, while the definition of Day also includes formal study. According to Harvey (2004), APEL is similar to APL in recognizing prior learning, but is broader in that it allows any form of prior experience.

In conclusion, many types of learning are the object of assessment (formal, non-formal and informal) with differing meanings (skills, competences). It is not directly possible to deduce the type of learning involved from the used term of abbreviation. With respect to the quality criteria of Baartman et al. (2006), this conclusion relates to the criteria of fitness for purpose and transparency. Transparency is not always met, because sometimes terms not covering the objective of the procedure are used and, therefore, fitness for purpose is not obvious.

The structure of APL In many of the definitions, the word process is used (see Table 2). In APL this progression proceeds in several phases. Evans (2003) divides the procedure into identifying, articulating and organizing learning with the aim of formulating clear statements of claims for knowledge and skill, which can then be recognized, assessed and accredited. These phases are also included in the definition of Human 
Resource Development (1995). The Calibre group of Companies (2003), Wilcox and Brown (2002), Scottish Qualifications Authority (1997), Thomas et al. (2000), Vanhoren (2002) and the New Zealand Qualification Authority (2001) distinguish the following phases:

(1) In the learner profiling phase, the institution gathers information about the learner's personal characteristics and needs. The resulting profile often provides the basis on which institutions select learners for APL. In this phase, the institution can inform the learners about the steps and expectations of the procedure. This phase is also referred to as "identification and initiation."

(2) In the phase of gathering and presenting the evidence (also called "documentation and preparation"), learners collect evidence about previous qualifications and experience in order to support a claim for credit with respect to the new qualification they are seeking. An important role is given to the learner. Often, a self-assessment is required in this phase. All APLs have one thing in common: learners have to prove that they have acquired knowledge, skills or competences that meet the requirements of the course or learning program they wish to follow (Evans, 2003).

(3) In the phase of assessing the evidence, assessors review the quality of the learner's evidence using assessment standards. The result of the assessment should be an answer to the question whether the learner should gain recognition (see "possible outcomes"). Independent of the assessor, the assessment should produce the appropriate outcome. The outcome should not be influenced by differences between, for example, assessors or tutors.

(4) The final phase of accreditation (or "recognition") involves the verification or endorsement by the department responsible for awarding the credit or recognizing the outcome of the assessment (see also "possible outcomes"). Pouget and Osborne (2004) emphasize the slight difference between the concept of "accreditation" and "validation." The latter is more general in the sense of "giving value." The Dutch Ministry of Economic Affairs (2000) distinguishes between the phases for an institution and the phases for a learner. For an institution, the phases consist of target definition, awareness development and a general preparation of the process. For a learner, the phases consist of an assessment and a follow-up advisory consultation. Also, after the accreditation, the learner may be supported by a follow-up in the development of a "personal development plan" or a "learning path" (Scholten \& Teuwsen, 2002; Thomas et al., 2000). 
With respect to the structure of APL, the quality criteria of transparency, comparability and selfassessment are important. According to the literature, the institution must have clear and operationalized descriptions of the educational program before starting the first phase. In other words, the structure must be transparent. The learning objectives must be clearly described in terms of competences, skills and knowledge. The procedure should directly match the educational program. The availability of assessment standards and trained assessors relates to comparability. The evidence should be in line with the type of learning objectives. If a self-assessment is used in the second phase that will be used by the assessors in the third phase, the fitness for self-assessment will increase. The possible outcomes of APL

The outcome of APL may be identification, recognition, assessment, accreditation or recommendation and can be assigned as results of the different phases in the process. Most of the procedures are aimed at assessing a learner so as to fit a preconceived outcome (Challis, 1996). Konrad (2001) relates these possible outcomes to levels of qualifications, varying from "competence in the performance of a range of varied work activities, most of which may be routine and predictable" (p. 1) to "competence which involves the application of a significant range of fundamental principles and complex techniques across a wide and often variety of contexts" (p. 1). Clarke and Warr (1997) distinguish four possible outcomes of APL: specific credit, modified specified credit, general credit and alternative credit. Specific credit can be claimed if a practitioner's learning matches a unit of learning. Modified specified credit can be claimed if a practitioner's learning can be captured through matching their learning with learning outcomes from a variety of units. General credit can be claimed when a practitioner identifies his or her own learning from unaccredited study, professional experience and personal experience. Finally, alternative credit is appropriate if a learner has been awarded credit in another institution of higher education. This corresponds with the outcomes of the Scottish Qualifications Authority (1997), namely entry into a course or program, credit within a program or course leading to a qualification, a certification of competence or a tailored-learning program for learning needs. In general, this means that APL can be used to admit learners to different stages in the educational program; it can be a function of entrance (at the start), positioning (during) or certification (at the end). 
In relation to the quality criteria of Baartman, clarity about the possible outcomes in the institution will increase fitness for purpose and transparency. The quality criterion of costs and efficiency is influenced by the possible outcomes. For example, if certification is to be the result, there will be no income from selling modules. The possible outcomes also influence the meaningfulness. If the profit is to be a certificate for one module, the surplus value for a learner is less than if the profit were to be an exemption from a larger part of the educational program. The assessment should be implemented only if positive effects are expected. The possible outcomes are part of these effects and are therefore related to educational consequences.

The benefits

APL is used to increase the accessibility to education ([Duvekot, 2001], [Evans, 2003] and [Konrad, 2001]; Scholten \& Teuwsen, 2002; [Scottish Qualifications Authority, 1997], [Thomas et al., 2000] and [Wheelahan et al., 2002]), to reduce drop-out rates (Pearson, 2004), to optimize the learning environment by introducing more facilities ([Bjørnavold, 2001] and [Ministry of Economic Affairs, 2000]; Scholten \& Teuwsen, 2002), for summative (certification) and formative reasons of assessment (Colardyn \& Bjørnavold, 2004; [Thomas et al., 2000], [Vanhoren, 2002] and [Wheelahan et al., 2002]), for a better connection between educational programs and the labor market (Andersson \& Fejes, 2005; Bélanger \& Mount, 1998; [Duvekot, 2001] and [Thomas et al., 2000]) and to emphasize lifelong and flexible learning (Bélanger \& Mount, 1998; [Blinkhorn, 1999], [Duvekot, 2001] and [Ministry of Economic Affairs, 2000]). Some researchers (Aarts et al., 2003; Andersson \& Fejes, 2005; [Blinkhorn, 1999] and [Konrad, 2001]; Taylor \& Clemans, 2000) stress the benefit of important efficiencies for parttime adult learners by shortening their programs, reducing course loads and reducing costs. Pires (2005) concludes that when learners have mixed motives, the benefits are personal rather than workrelated.

In relation to the quality criteria of Baartman, these benefits are important for meaningfulness, fitness for purpose, educational consequences and costs and efficiency. Meaningfulness increases if APL has a surplus value for both the institution and the candidates. The fitness for purpose increases if the information supply for prospective candidates only describes those benefits that are relevant for the purpose of the institution. If there are no benefits to be expected, an institution should consider the 
implementation of APL to meet the criterion of educational consequences. The benefits relate to costs and efficiency, because APL can lead to income for the institution, and time and effort for the learner. The methods In the phase of assessing the evidence (see "the structure of APL"), institutions use a variety of assessment methods. In this context, APL can be seen as a competency assessment program. Examples of applied assessment methods are: portfolio reviews, standardized commercial available exams, exams developed by college faculty, transcript reviews, essays, nonacademic course reviews, simulations, oral presentations, interviews, performances, demonstrations and course analogues (Fjortoft \& Zgarrick, 2001; Starr-Glass, 2002; Starr-Glass \& Schwartzbaum, 2003; Taylor \& Clemans, 2000). In APL it is important to select good methods for assessing who is competent enough to be admitted into a learning program (Andersson \& Fejes, 2005). The assessment methods need to be appropriate to the subject matter under evaluation (Abbott, 1992).

The most common method for presenting the evidence is the portfolio (Bjørnavold, 2001; Clarke \& Warr, 1997). A portfolio is a composition of work that a learner has selected and collected to show knowledge, skills or competences, and includes the reflections of the learner on the selected and collected work (Barrett, 2003). A portfolio, in other words, presents the evidence of a learner's prior learning. It is regarded as being one of the best instruments for visualizing and evaluating competencies acquired in informal or non-formal contexts (Bjørnavold, 2001). According to Clarke and Warr (1997) a portfolio document is well received by advisors and assessors as one approach to structuring the evidence. In support of learners in APL, a clear portfolio template and worked out examples are helpful for structuring the claim of the learner ([McMullan et al., 2003] and [Nyatanga et al., 1998]). The portfolio should be clear and appropriately organized, and it is important that learners receive clear guidelines as to its purpose, content and structure. The structure of the portfolio serves as a guide that supports the learner through the process and it should fit the learner's prior formal, informal and non-formal learning and the competences required by the institution (Baume \& Yorke, 2002; Bjørnavold, 2001; Mak, Scholten, Teuwsen, \& Sikkema, 2005; McMullan et al., 2003; Wilcox \& Brown, 2002). In its relationship to the qualification the learner wants to achieve, the evidence should fit the following criteria: 
- Educationally relevant. There should be a clear relationship between the evidence and the aims of the educational program ([Aarts et al., 2003] and [Scottish Qualifications Authority, 1997]).

- Transferable. The evidence should incorporate different kinds of requisite experiences (Cantwell and Scevak, 2004).

- Appropriate level. The level should match the formal educational program (Aarts et al., 2003).

- Valid. The evidence should focus on the appropriate competences, knowledge and skills specified in the standards of the educational program (Bateman et al., 2003; Colardyn \& Bjørnavold, 2004; Day, 2001a; Fahy, Periin, \& Ferrer, 1999; Starr-Glass, 2002);

- Authentic. The evidence needs to relate to prior learning and the learner must have undertaken what is claimed ([Day, 2001a], [Konrad, 2001] and [Scottish Qualifications Authority, 1997]).

- Specific, identified and categorized and recent. The evidence should be appointed to specific situation, task and activity of the candidate and recent means that it should be current for the learning objectives involved ([Konrad, 2001] and [Scottish Qualifications Authority, 1997]; Thomson, Saunders, \& Foyster, 2001).

- Sufficient. The amount of evidence should match what is necessary to demonstrate competences, knowledge or skills. Sufficiency depends on the objective. To proof a specific quality, one piece of evidence might be sufficient, to proof work in several environments needs a minimum of two pieces of evidence (Scholten \& Teuwsen, 2002; Scottish Qualifications Authority, 1997).

The assessors play an important role in the assessment phase. Content area expertise and an understanding of and agreement with the philosophy and process of the procedure are crucial requirements (Abbott, 1992).

The methods that are used in APL concern the quality criteria fitness for purpose, transparency, acceptability, comparability, cognitive complexity, reproducibility of decisions and fitness for selfassessment. For the most part, the methods referred to in the literature fit the objective of APL. In these cases, fitness for purpose has been met. The literature also addresses the availability of assessment criteria and trained assessors. This will increase transparency, acceptability, comparability and the reproducibility of decisions. Some of the literature mentions that the learner should be involved in self-assessment. In that case, fitness for self-assessment would be satisfied. 
The assessor must determine whether the informal learning experience is at an appropriate level (Abbott, 1992) because "the learning is important, but the quality of the learning as ascertained via comprehensive evaluation is paramount" (Freed, 2006, p. 11). This relates to the criterion of cognitive complexity: the learners prove the acquisition of higher cognitive skills, which represent the level of the educational program.

The support of the learners

APL requires a high level of responsibility on the part of the learners. They are responsible for providing the evidence for acquired competencies, based on a description of the competencies and criteria for presentation in a portfolio (Colley, Hodkinson, \& Malcolm, 2002). Therefore, learners should be able to articulate learning needs and achievements (Cretchley \& Castle, 2001), reflect on their own competences and prepare their own competence profile (Onderwijsraad, 2003). However, Shapiro (2003) shows that learners find it difficult to give good descriptions of former learning. They are not always aware of the extent of what they know or lack the language skills to articulate this knowledge adequately (Wheelahan et al., 2002). Moreover, the perception of informal learning is subjective, not all learners learn well from experience and it is difficult to assess whether past job experiences actually contribute to the acquisition of competences or skills (Colley, Hodkinson, \& Malcolm, 2002; [Fahy et al., 1999] and [Shapiro, 2003]; Spencer, Briton, \& Gereluk, 2000; Wheelahan et al., 2002). Finally, it is only the learning that has to be demonstrated and awarded with credit, not the experience itself (Andersson \& Fejes, 2005; Day, 2001b).

Because of this difficult process of self-evaluation of non-formal and informal prior learning experiences and composing a portfolio, learners need support in gathering the appropriate evidence (Ministry of Economic Affairs, 2000; Scholten, Teuwsen, \& Mak, 2003; [Scottish Qualifications Authority, 1997], [Thomas et al., 2000] and [Wheelahan et al., 2002]). Cleary et al. (2002) state that it is important that learners feel confident about the process of learning, especially if the learners are adult returnees or other types of learners who lack self-confidence. Self-assessment and reflection provide a better understanding of one's own learning in relation to the learning objectives of the educational program. Reflecting on experiences means that people learn not only about themselves, but they also discover what was significant about the experiences they are investigating (Evans, 2003). This will lead to increased self-knowledge and more self-confidence. According to Colardyn and 
Bjørnavold (2004), proper support is required for all methods of collecting evidence of learning, such as examination, observation and simulation. The support of the learners must be organized in such a way that the criteria for the evidence are feasible. In a pilot study of Scheltema (2002), learners indicated that they knew what was expected of them, but it appeared that the assessors needed to give more advice in adapting the evidence supplied so it would form appropriate evidence.

Different kinds of support are outlined by Cleary et al. (2002), varying from learners who work by themselves with minimal contact with a tutor, to procedures organized through regular meetings with a tutor. Some institutions oblige learners to participate in a formal educational course if the latter apply for some sort of exemption. Clarke and Warr (1997) describe how preparatory workshops are effective and a vital part of the accreditation process. Day (2001b) is explicit in the support for learners: help the learner to identify relevant learning, agree to and review an action plan for the demonstration of prior learning, and help the learner to prepare and present evidence for assessment. Donoghue et al. (2002) describe extensive assistance strategies including writing skills workshops, library orientations, acknowledgment of learner needs in the classroom, invitations to discuss with the staff, critical thinking and analysis, literature searches, the application of literature findings, the development of a position and use of argument and referencing procedures. The style of support should be focused on directing, encouraging, setting deadlines and discussing (Clarke \& Warr, 1997). Meetings might be on a one-toone basis or could involve groups of learners meeting with a tutor to discuss common issues. Peer support can also be of importance. Although the process is based on the personal nature of some of the experiences, reflection can be carried out with others in a group setting. The advisability of this approach has to be carefully considered by tutors and may depend on the types of learners involved. Ideally, the learners themselves should be offered a choice of approach. Cleary et al. (2002) state that "perhaps the most important issue in relation to support and guidance is that of structure. If a clear structure of support and guidance is in place the learners will be much clearer about how the process works in general" (p. 14). This statement underlines the relevance of transparency in student support in APL. The way the role of the learner is described is in line with the criterion of fitness for selfassessment.

Time investment 
Although there is no accurate information about the amount of time needed for learners and institutions when using APL, the overall impression is that it is time-consuming (Bélanger \& Mount, 1998; The Calibre group of Companies, 2003; Taylor \& Clemans, 2000; [Thomas et al., 2000] and [Wheelahan et al., 2002]). Aarts et al. (2003) point at the need for renewed emphasis on training that supports the development of cost-efficient and valid assessment tools. Especially in the phase where the institution has to assess the evidence, time can be saved if the evidence presented is in conformity with the qualitative requirements of the institution (Thomas et al., 2000). In spite of these negative arguments, one of the benefits is that APL represents important efficiencies for part-time adult learners by shortening their programs, reducing course loads and reducing costs ([Aarts et al., 2003], [Blinkhorn, 1999] and [Konrad, 2001]). According to Blinkhorn (1999), by going through the portfolio process, learners viewed their prior learning as a way to decrease the time necessary to complete their programs. Writing a portfolio reduces duplication of learning if the portfolio is successful and if an individual receives academic credit. In addition, Clarke and Warr (1997) conclude that the timeconsuming nature of portfolio preparation did not apply to portfolio construction in APL if the time allotted for advice was adequate.

Successful implementation of APL requires a solution for time-consuming and bureaucratic procedures, otherwise it will reduce access to the procedures ([Duvekot, 2001] and [Thomas et al., 2000]). The costs of these procedures depend on the procedure and the available experience and tools (Thomas et al., 2000). Aarts et al. (2003) show that there can be a balance between the result of the procedure and the effort delivered, thereby satisfying the quality criterion for costs and efficiency.

\section{Summary}

The results presented in the previous give an overview of the characteristics of APL: the type of learning, the structure of the procedure, the possible outcomes of the procedure, the benefits, the methods, the support for the learner and the time investment. At the end of the description of each characteristic, the relationship to the quality framework of Baartman was outlined. Table 3 gives an overview of this relationship. A bullet indicates that the quality criterion (row) is influenced by the characteristic (column). 
Implications for Designing APL

In the following section, the relationship between characteristics and quality criteria will be discussed by giving guidelines for designing APLs that comply with the quality framework of (Baartman et al., 2006) and (Baartman et al., 2007).

1) Fitness for purpose

Fitness for purpose is the basis for the development of all competency assessment programs (Baartman et al., 2006). This means that APL must be aligned with the goal of the educational program. The criterion "fitness for purpose" will improve if institutions choose those benefits and outcomes of APL that suit the purpose of the educational institution, and a term and abbreviation that suit the intention of the procedure. To assess fitness for purpose it is necessary to have information about the combination of used term and a definition. In addition, the choice of assessment methods should fit the purpose of the educational program. In spite of the literature that shows portfolio assessment as the most common way of compiling evidence of prior learning, it is not obligatory to use a portfolio assessment. In other words, if competences are to be measured, competence assessment should be expected; if knowledge is to be measured, a knowledge test would probably be more appropriate. Overall, it is clear that the procedure is not a goal in itself, but simply an instrument that helps to support people's lifelong personal development (Fjortoft \& Zgarrick, 2001). If this is the purpose of an educational program, then APL might be a suitable method.

\section{2) Transparency}

Many aspects of the characteristic of APL are related to the quality criterion of transparency. First, designers should be clear about what type of learning (formal, non-formal and informal) and what kind and level of content (knowledge or competences or skills) are required and what the possible outcomes of this procedure can be for the learner. Transparency increases when using a term for the procedure to assess and credit prior learning that covers the purpose of the procedure. The whole procedure for selecting and presenting evidence should be transparent and learners should be supported in their portfolio construction and self-assessment. The following needs to be clear to learners: (1) the prior learning required described in terms of competencies, knowledge and skills; (2) the possible outcomes; (3) the form in which the evidence should be presented; (4) the assessment method and assessment standard; (5) the support that is offered to the learner by the institution for 
self-assessment and portfolio construction. The assessors and other people concerned, such as a tutor, should be trained. If transparency is guaranteed, participants will be more inclined to accept the procedure and evaluate it as fair because the expectation of the procedure will correspond with reality.

\section{3) Acceptability}

Acceptability is about the acceptance of all stakeholders (assessors, tutors, management, workfield, ...) of the structure of the procedure, the relationship between investment in the procedure and benefit from the procedure, the instruments, the selected assessment methods and the responsibilities of the persons concerned. If it is decided that besides a portfolio assessment, a knowledge test is part of the APL procedure, the APL designers should focus on the acceptance of these assessment instruments by assessors and learners. Acceptability increases if the APL is transparent and decisions are reproducible because the expectation of the procedure will correspond with reality.

4) Reproducibility of decisions

According to Baartman et al. (2007), reproducibility of decisions address the fact that (high-stakes) decisions made about students should be based on multiple assessments, carried out by multiple assessors and on multiple occasions. Abbott (1992), Baume and Yorke (2002) and Cretchley and Castle (2001) support this criterion by emphasizing the availability of several assessment methods. Besides, assessment criteria should be available and described properly, and the assessors should be trained. The use of external assessors from the labor market in addition to internal assessors, as well as learners as assessors, might improve the reproducibility of decisions. The structure of the procedure should be the same for all participants so as to increase the reproducibility of decisions.

5) Comparability

To improve comparability, it is important that the structure of APL is consistent and standardized. The conditions under which APL is carried out should be the same for all learners and scoring should be consistent. Assessment standards must therefore be available. For the implementation of APL in an educational context, it is important to plan assessor sessions in which assessors exchange their assessment experiences, assess the same portfolio and share their judgments to reduce differences in assessment judgments.

6) Fairness 
Fairness will increase if transparency is satisfied. Learners will evaluate APL as fair if the expectation of the procedure corresponds with reality. The methods used to assess prior learning should not disadvantage learners in their delivering of the appropriate evidence. Generally speaking, the existence of APL depends on the criterion of fairness: "If experienced adults had gained academically equivalent learning through work, volunteer activity, and independent study, that learning should be formally acknowledged. [...] APL was simply one more version of the ways in which students had always demonstrated their college-level learning: essays and term papers, demonstrations, interviews with faculty, and course-specific and standardized exams." (Michelson, 1997, p. 41).

7) Cognitive complexity

Cognitive complexity is related to the quality criterion of fitness for purpose, because the evidence learners deliver should represent the level of the educational program. The expected level of prior learning should be clear to the learners, yet the literature gives many examples of difficulties in delivering this evidence at the appropriate level. In this context, Shalem and Steinberg (2002) mention the difference between retrospective and prospective assessment. In retrospective assessment, the learner demonstrates the competence already acquired, while prospective assessment refers to the readiness of the learner to join a qualification or to learn at an appropriate level in an educational program. APL should cover both to support this cognitive complexity. Designers should choose only those assessment methods that match the cognitive level of the educational program.

8) Fitness for self-assessment

The quality criterion of fitness for self-assessment is important in the second phase of APL, namely in selecting and presenting the evidence. In this phase, an important role is assigned to the learner, because a self-assessment is often required. Self-assessment provides a better understanding of one's own learning in relation to the learning objectives of the educational program. This will lead to increased self-knowledge and more self-confidence. Moreover, guidance and support are needed because the gathering of evidence consists of several sub-skills, namely identifying relevant learning, evaluating one's own experiences, reflecting on one's own competences and preparing one's own competence profile. The support should be directed towards the identification of relevant learning, reflection on one's own competences, gathering of the appropriate evidence, and presentation of the evidence in line with the assessment demands of the institution. This might consist of preparing a 
demonstration or a presentation, but in most cases, it is the composition of a portfolio with the appropriate evidence. In addition, extra study-skills support can be given such as writing skills workshops, library orientations, critical thinking and analysis, and literature searches to improve the connection to the formal learning environment. For example, Bowling Green State University has designed an online writing course for adults in a prior learning assessment program (Blair \& Hoy, 2006).

9) Meaningfulness

APL is only meaningful if the procedure has a surplus value for the institution as well as for the learners. If there are no benefits to be expected for the institution or for the learner, the procedure should not be implemented. It is important here to be aware that what is meaningful for one person is not always meaningful for another person. For the design of APL, this means that the benefits for both the learner and the institution must be described in clear and transparent terms. The phases of the procedure should be developed in a way that is meaningful for all people involved.

10) Authenticity

The literature on APL provides little information related to the quality criterion of "authenticity." A reason for this might be that APL is organized at the start of an educational program. Learners who participate in APL are often experienced workers. If this work experience is relevant to the educational program, they can start the APL procedure. However, one of the criteria of the evidence learners provide is that it should be authentic, which means that it belongs to the prior learning and the learner has undertaken what is claimed (Konrad, 2001). This definition differs from that of Baartman, who states that the tasks a learner has to fulfill should have a direct link with future practice (Gulikers et al., 2004).

11) Educational consequences

At the start of an APL procedure, the educational consequences should be clear and negative effects should be prevented. According to Andersson (2006), an educational consequence of the implementation of a new assessment method like APL is that the institution should be open to change in its way of thinking about learning and assessment, and about what could and should be assessed. This consequence should be taken into account by designers in processes in which educational innovation is desired. 


\section{2) Costs and efficiency}

The quality criterion of costs and efficiency has received little attention in the literature, contrary to the oft-mentioned importance of an efficient and effective procedure. The overall impression is that APL is time-consuming (Bélanger \& Mount, 1998; The Calibre group of Companies, 2003; Taylor \& Clemans, 2000; [Thomas et al., 2000] and [Wheelahan et al., 2002]), but can be made efficient by differentiation in procedure and through the availability of experience and proven tools (Thomas et al., 2000). Giving support to the learner is an important factor in the time spent by tutors on APL. According to Thomas et al. (2000), the institution can reduce the time it invests in the phase of assessment of the evidence if the presented evidence fits the institution's desired level. To reach this prerequisite (advancing the presented evidence to a higher level), the institution should focus on the support of learners in the phase of gathering and presenting the evidence. The choice of a certain outcome involves the costs of the procedure for the learner as well as the institution. A right balance between the result of APL and the effort delivered by the learner and the institution can optimize costs and efficiency. For the institution this means, for example, an increase in learner numbers and for the learners this means a reduction in the learning period.

\section{Conclusion and Discussion}

This study focused on the following research question: How are the characteristics of APL elaborated in the literature and what is the relationship between APL and the quality framework for competency assessment programs? Based on this study, design guidelines for APL can be formulated.

Regarding the characteristics of APL, we can conclude that, although differences in terms, types of learning and possible outcomes were described, a large overlap was found in the structure of APL procedures and the used assessment methods to provide evidence of prior learning. Many of the benefits of APL are known, in contrast to the oft-mentioned inefficiency of APL. The procedures require a high level of responsibility from learners and support in the complex task to compose a portfolio.

A second conclusion is that the quality framework of Baartman et al. is useful for APL, but that some of the criteria are more relevant than others. Authenticity, defined by Gulikers et al. (2004) and used by Baartman et al. has a different perspective in APL than in competency assessment programs during formal education. By optimizing the quality of APL, lifelong learning will be stimulated. 
A point of discussion is that Baartman et al. (2006) stated that there was interdependency between the second level of criteria (transparency, acceptability, reproducibility and comparability) and the third level of criteria (fairness, cognitive complexity, fitness for self-assessment, meaningfulness and authenticity). The question is if this interdependency is really as clear as Baartman et al. stated. Acceptability, for example, seems to be dependent on transparency and comparability of decisions. If transparency is satisfied for all aspects of APL and decisions are comparable, participants will be more inclined to accept the procedure and evaluate it as fair. The interdependency could be a problem if one wants to investigate APL with these criteria empirically. In point of fact, the distinction between reproducibility of decisions and comparability of decisions is difficult. The emphasis on the reproducibility of decisions about the availability of more than one type of assessor leads to an increase in comparability. On the other hand, to improve comparability, it is important that the structure of APL is consistent and standardized. The introduction of more assessors complicates the standardization in work processes.

For APL, as well as for other competency assessment programs, fitness for purpose is an important basic criterion. This is where the role of the designer starts. The designer has the complex task of developing an APL procedure that meets the quality framework. The cost and efficiency criterion is essential because an APL procedure "can be correctly designed according to all criteria, but if it cannot be implemented and used because of prohibitively high costs or low efficiency, the development has been a waste of time" (Baartman et al., 2006, p. 167).

The literature about APL is mainly descriptive. In order to learn more about the quality of APL it is important to put APL on the empirical research agenda. What will be the effect of APL in the long term? Do students admitted to an educational program in the traditional way differ after certification from students admitted to the program through APL? In addition to this literature review, the perceptions of learners, tutors, assessors and designers should be explored in depth in future research in order to design high-quality APL procedures. Finally, how learners can be supported in these procedures also needs to be investigated, since one important result of this study was that learners are not automatically able to evaluate their own experiences and to present these in a portfolio.

Acknowledgements 
We like to thank the three anonymous reviewers for their scholarly comments.

\section{References}

Aarts, S., Blower, D., Burke, R., Conlin, E., Lamarre, G., McCrossan, W., \& Van Kleef, J. (2003).

Feedback from Learners: A Second Cross-Canada Study of Prior learning Assessment and Recognition. Cross-Canada Partnership of PLAR.

Abbott, L. C. (1992). Prior learning Assessment: Faculty Evaluator Training and Development. Unpublished doctoral dissertation, National-Louis University.

Andersson, P. (2006). Caretakers' experiences of RPL. Journal of Vocational Education and Training, $58,115-133$.

Andersson, P., \& Fejes, A. (2005). Recognition of prior learning as a technique for fabricating the adult learner: a genealogical analysis on Swedish adult education policy. Journal of Education Policy, 5, 595-613.

Baartman, L. K. J., Bastiaens, T. J., Kirschner, P. A., \& Van der Vleuten, C.P.M. (2006). The wheel of competency assessment. Presenting quality criteria for Competency Assessment Programmes.

Studies in Educational Evaluation, 32, 153-177.

Baartman, L. K. J., Bastiaens, T. J., Kirschner, P. A., \& Van der Vleuten, C.P.M. (in press). Evaluating assessment quality in competence-based education: A qualitative comparison of two frameworks. Educational Research Review, doi:10.1016/j.edurev.2007.06.001.

Benett, Y. (1993). The validity and reliability of assessments and self-assessments of work-based learning. Assessment \& Evaluation in Higher Education, 18, 83-95.

Barrett, H. C. (2003). Electronic Portfolio. In A. Kovalchick, \& K. Dawson (Eds.), Educational Technology; an Encyclopedia. : ABC-CLIO, Santa Barbara, CA.

Bateman, A., \& Knight, B. (2003). Giving credit. A review of RPL and credit transfer in the vocational education and training sector, 1995 to 2001. Australian National Training Authority. Retrieved November 12, 2004 from www.ncver.edu.au Baume, D., \& Yorke, M. (2002). The reliability of assessment by portfolio on a course to develop and accredit teachers in higher education. Studies in Higher Education, 27, 7-25.

Bélanger, C. H., \& Mount. J. (1998). Prior learning Assessment and Recognition (PLAR) in Canadian Universities. The Canadian Journal of Higher Education, 28, 99-119 
Bjørnavold, J. (2001). Making learning visible: identification, assessment and recognition of non-formal learning. European Journal, 22, 24-32.

Blair, K., \& Hoy, C. (2006). Paying attention to adult learners online: the pedagogy and politics of community. Computers and Composition, 23, 32-48.

Blinkhorn, K. W. (1999). Prior learning Assessment: An Investigation of Nonsponsored Learning for College Credits. Unpublished doctoral dissertation, The Ontario Institute for Studies in Education/University of Toronto, Canada.

The Calibre group of Companies (2003). Needs assessment of a prior learning assessment and recognition process for the nursing education program of Saskatchewan. Final report.

Cantwell, R. H., \& Scevak, J. J. (2004). Engaging university learning: the experiences of students entering university via recognition of prior industrial experience. Higher Education Research \& Development, 23, 2, 132-145.

Challis, M. (1996). Andragogy and the accreditation of prior learning: points on a continuum or uneasy bedfellows? International Journal of Lifelong Learning, 15, 32-40.

Clarke, J. B., \& Warr, J. (1997). Academic validation of prior and experiential learning: evaluation of the process. Journal of Advanced Nursing, 26, 1235-1242.

Cleary, P., Whittaker, R., Gallacher, J., Merrill, B., Jokinen, L., \& Carette, M. (2002). Social Inclusion through APEL: the Learners' Perspective. National Report prepared for the EC: Socrates-Grundtvig Project, Glasgow: Centre for Research in Lifelong Learning. Retrieved June 8, 2004 from

\section{http://crll.gcal.ac.uk/SOCRATESSite/ComparativeReport.pdf.}

Colardyn, D., \& Bjørnavold, J. (2004). Validation of formal, non-formal and informal learning: policy and practices in EU Member States. European Journal of Education, 39, 69-89.

Colley, H., Hodkinson, P., \& Malcolm, J. (2002) Non-formal learning: mapping the conceptual terrain. A Consultation Report, Leeds: University of Leeds Lifelong Learning Institute. Also available in the informal education archives: http://www.infed.org/archives/e-

texts/colley_informal learning.htm.

Cretchley, G., \& Castle, J. (2001). OBE, RPL and adult education: good bedfellows in higher education in South Africa? International Journal of Lifelong Education, 20, 487 - 501 
Day, M. (2001a). Developing benchmarks for prior learning assessment. Part 1: research. Nursing Standard. 15(34), 37-44.

Day, M. (2001b). Developing benchmarks for prior learning assessment. Part 2: practitioners. Nursing Standard. 15(35), 38-44.

Dierick, S., \& Dochy, F.J.R.C. (2001). New lines in edumetrics: New forms of assessment lead to new assessment criteria. Studies in Educational Evaluation, 27, 307-329.

Donoghue, J., Pelletier, D., Adams, A., \& Duffield, C. (2002). Recognition of prior learning as university entry criteria is successful in postgraduate nursing students. Innovations in Education and Training International, 39, 54-62.

Duvekot, R. (2001). The dynamics of non-formal learning and the opening-up of national learning systems. In D. Colardyn (Ed.)., Lifelong Learning: Which Ways forward? (pp. 58-68). College of Europe.

Duvekot, R. (2005). VPL in 10 steps. In R. Duvekot, K. Schuur, \& J. Paulusse (Eds.), The unfinished story of VPL. (pp. 11-27). Utrecht: Foundation EC-VPL \& Kenniscentrum EVC.

Evans, N. (2003). Making sense of lifelong learning: respecting the needs of all. London: RoutledgeFalmer.

Fahy, K., Periin, C., \& Ferrer, J. (1999). Accreditation of Prior Experiential Learning: reaching a standard or jumping through hoops. Australian Electronic Journal of Nursing Education, 4(2). Retrieved December 16. 2004 from http://www.scu.edu.au/schools/nhcp/aejne/archive/vol42/fahykvol4_2.htm

Fjortoft, N. F., \& Zgarrick, D. P. (2001). Survey of prior learning assessment practices in pharmacy education. American Journal of Pharmaceutical Education. 65, 44 - 53.

Freed, R. (2006). An investigation of prior learning assessment processes in Texas public universities offering nontraditional baccalaureate degrees. Dissertation Abstracts International, 67 (4), 1185.(UMI No. 3214466).

Gulikers, J. Bastiaens, Th., \& Kirschner, P. (2004). A five-dimensional framework for authentic assessment. Educational Technology Research \& Development, 52(3), $67-$ 85. 
Hambleton, R. K. (1996). Advances in assessment models, methods, and practices. In D. C. Berliner, \& R. C. Calfee (Eds.), Handbook of educational psychology (pp. 899-925). New York: MacMillan.

Harvey, L. (2004). Analytic Quality Glossary. Quality Research International. Retrieved May 28, 2004 from http://www.qualityresearchinternational.com/glossary/

Human Resource Development (1995). Prior learning Assessment Newsletter, 1(2). Retrieved May 28, 2004 from http://fcis.oise.utoronto.ca/ p plar/

Konrad, J. (2001). Accreditation of Prior Experiential Learning in the United Kingdom. Working paper. Leeds: Metropolitan University. Retrieved January 10, 2005 from

http://www.leeds.ac.uk/educol/documents/00001831.htm.

Koper, E.J.R., Rusman, E., Sloep, P. (2005). Effective Learning Networks. Lifelong learning in Europe, $1,18-27$.

Linn, R. L., Baker, J., \& Dunbar, S. B. (1991). Complex, performance-based assessment: Expectations and validation criteria. Educational Researcher, 20, 15-21.

Livingstone, D. W. (2000). Exploring the icebergs of adult learning: findings of the first Canadian survey of informal leaning practices. The Canadian Journal for the Study of Adult Education. 13, 2, 4972.

Mak, A. M., Scholten, A. Sikkema, F. \& Teuwsen, R. (2005). Portfolio for the enrolment of refugee doctors in the Dutch medical science programme.

McMullan, M., Endacott, R., Gray, M. A., Jasper, M., Miller, C. M. L., Scholes J., et al. (2003).

Portfolios and assessment of competence: a review of the literature. Journal of Advanced Nursing, 41, 283-294.

Michelson, E. (1997). Multicultural Approaches to Portfolio Development. New Directions for Adult and Continuing Education, 75, 41-53.

Ministry of Economic Affairs. (2000). De Fles is Half Vol. Een brede visie op de benutting van EVC.

[The bottle is half-full.]. Ministry of Economic Affairs; Den Haag.

New Zealand Qualification Authority (2001). Learning and assessment. A guide to assessment.

Wellington: New Zealand Qualification Authority. 
Nyatanga, L (1993) APL: some international perspectives. British Journal of Nursing, 2, 892-893.

Nyatanga, L., Forman, D., \& Fox, J. (1998). Good Practice in the Accreditation of Prior learning. London: Casell.

Onderwijsraad (2003). Werk maken van een leven lang leren. [Making work of lifelong learning]. Den Haag: Onderwijsraad.

Pearson, W. (2004). Supporting adult student persistence to the baccalaureate degree. Journal of Continuing Higher Education, 52, 4, 23-26.

Pires, A. L. (2005). Educaçao e Formaçao ao Longo da Vida: análise crítica dos sistemas e dispositivos de reconhecimento e validação de aprendizagens e de competências. Dissertation, Lisbon: MCES / FCGulbenkian.

Pouget, M., \& Osborne, M. (2004). Accreditation or validation of prior experiential learning: knowledge and saviors in France - a different perspective? Studies in Continuing Education, 26, 45-65.

Quality Assurance Agency for Higher Education. (2004). Guidelines on the accreditation of prior learning. London, UK: Author. Retrieved November 8, 2006 from http://www.qaa.ac.uk/academicinfrastructure/apl/APL.pdf Scheltema, L. (2002). Rapportage project EVC-i 2002. [Report APL project]. Woerden: Stichting LOB Intechnium. Retrieved June 14, 2004 from

\section{http://www.intechnium.nl/images/RapportEVCi2002.pdf}

Scholten, A. M., \& Teuwsen, R. (2002). Linking ICE and PLAR: overview of the developments in the Netherlands. Den Haag: Nuffic.

Scholten, A. M., Teuwsen, R., \& Mak, A. M. A. (2003). Portfolio-ontwikkeling door buitenlandse artsen. [Portfolio development by foreign doctors]. Kenniscentrum EVC. Retrieved May 28, 2004 from http:// www.kenniscentrumevc.nl/site/documenten/Portfolio_geneeskunde_studenten.pdf Scottish Qualifications Authority (1997). Identification, validation and accreditation of prior and informal learning. UK report. Thessaloniki: CEDEFOP.

Shalem, Y., \& Steinberg, C. (2002). Invisible criteria in a portfolio-based assessment of prior learning: a cat and mouse chase. Pedagogy, Culture and Society, 10, 425-448. 
Shapiro, J. (2003). Exploring teachers' informal learning for policy on professional development. Unpublished doctoral dissertation, RAND. Retrieved April 19, 2004 from http://www.rand.org/publications/RGSD/RGSD174/

Sluijsmans, D., Straetmans, G., \& Van Merriënboer, J.J.G. (submitted). Integrating authentic assessment with competence-based learning: The Protocol Portfolio Scoring-Method.

Spencer, B., Briton, D., \& Gereluk, W. (2000). Crediting Adult Learning. Proceedings of the 41st Annual Adult Education Research. Athabasca University. Retrieved November 15, 2004 from http://www.edst.educ.ubc.ca/aerc/2000/spencerbetal1-final.PDF.

Starr-Glass, D. (2002). Metaphor and Totem: exploring and evaluating prior experiential learning. Assessment, \& Evaluation in Higher Education. 27, 3, 221 - 231.

Starr-Glass, D., \& Schwartzbaum, A. (2003). A Liminal Space: challenges and opportunities in accreditation of prior learning in Judaic Studies. Assessment, \& Evaluation in Higher Education. 28, 2, $179-192$.

Taylor, T, \& Clemans, A. (2000). Avoiding the Hoops: a study of recognition of prior learning processes in Australian faculties of education. Asia-Pacific Journal of Teacher Education, 28, 263-280. Thomas, E., Broekhoven, S., \& Frietman, J. (2000). EVC aan de poorten van het hoger onderwijs. [APL at the gateway of higher education]. Nijmegen: ITS. Retrieved May 28, 2004 from http://www.minocw.nl/onderwijs/evc/.

Thomson, P., Saunders, J., \& Foyster, J. (2001). Improving the validity of competency-based assessment, NCVER, Adelaide. Retrieved June 20, 2005 from

http://www.ncver.edu.au/research/proj/nr9035.pdf.

Vanhoren, I. (2002). Van herkennen naar erkennen. [From identifying to recognizing]. Leuven: Katholieke Universiteit Leuven.

Wheelahan, L., Miller, P., \& Newton, D. (2002). Thinking about RPL: A framework for discussion. Paper presented at $11^{\text {th }}$ National VET Training Research Conference, Brisbane, Australia.

Wilcox, J., \& Brown, R. (2002). Accreditation of prior and experiential learning. Bradford: UK Centre for Materials Education. 
Table 1.

The Definitions of the Quality Criteria

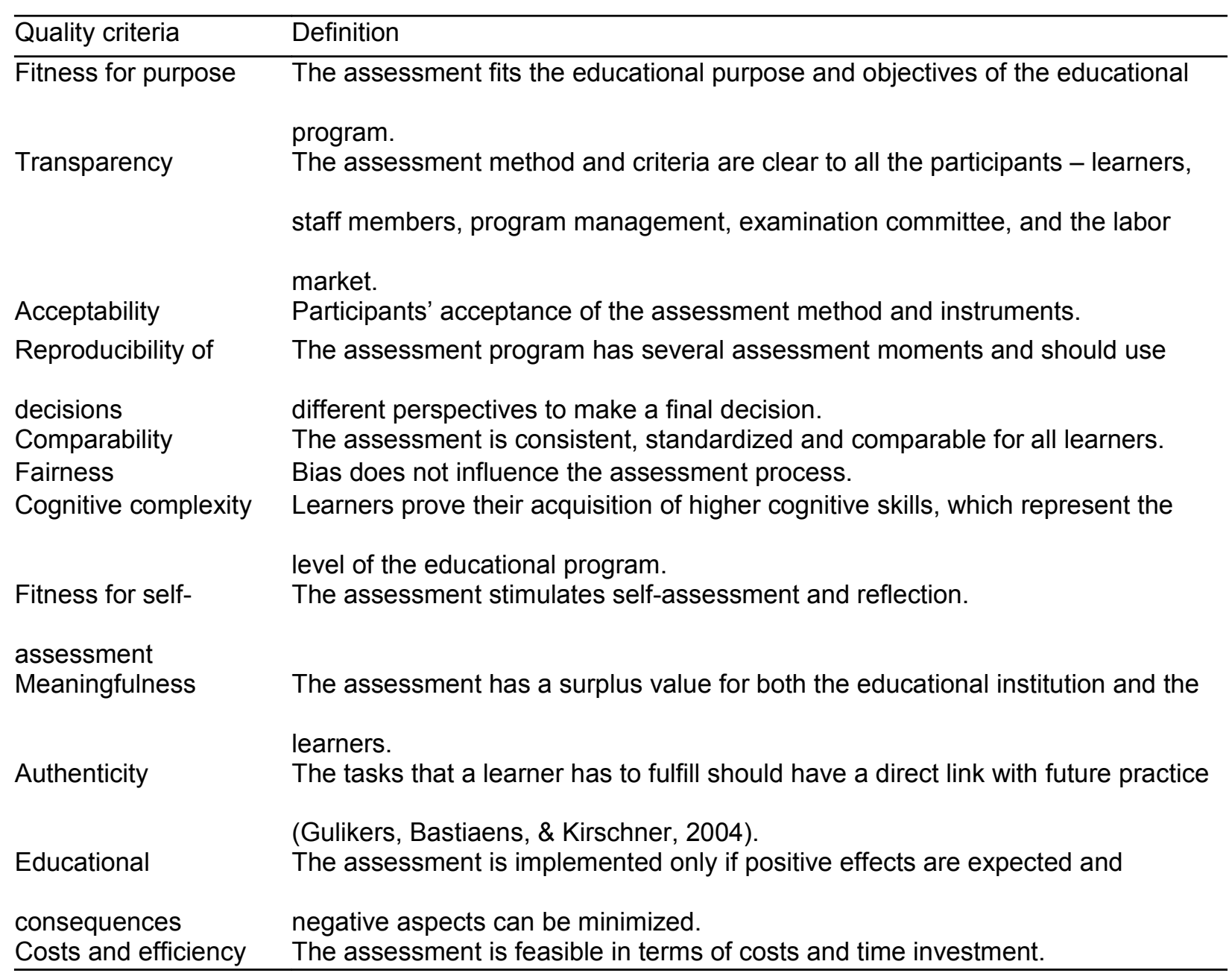


Table 2.

Overview of the terms and abbreviations in relation to the type of learning

\begin{tabular}{|c|c|}
\hline Term / abbreviation & Type of learning \\
\hline Accreditation of Prior & $\begin{array}{l}\text { - learning that has occurred at some time in the past in a program of study, or } \\
\text { experience gained at work, or during voluntary activities (Day, 2001a; Scottish } \\
\text { Qualifications Authority, 1997) } \\
\text { - learners' previous learning in a program of study (Harvey, 2004) } \\
\text { - prior experiential learning or prior certificated learning (Quality Assurance } \\
\text { Agency for Higher Education, 2004) } \\
\text { - academic output by non-accredited institutions (Starr-Glass \& Schwartzbaum, } \\
\text { 2003) }\end{array}$ \\
\hline $\begin{array}{l}\text { Assessment of Prior } \\
\text { learning (APL) }\end{array}$ & - learning not restricted to academic settings or curricula (Starr-Glass, 2002) \\
\hline $\begin{array}{l}\text { Prior learning } \\
\text { Assessment (PLA) }\end{array}$ & $\begin{array}{l}\text { - prior learning, acquired through study, work, and other life experiences, not } \\
\text { recognized through formal mechanisms (Blinkhorn, 1999) } \\
\text { - all acquired learning: knowledge, skills, values or competences (Day, 2001b; } \\
\text { Evans, 2003; Fjortoft \& Zgarrick, 2001; Human Resource Development, 1995) } \\
\text { - learning acquired outside the formal educational setting (Freed, 2006) }\end{array}$ \\
\hline $\begin{array}{l}\text { Accreditation of Prior } \\
\text { Experiential Learning } \\
\text { (APEL) }\end{array}$ & $\begin{array}{l}\text { (1) Prior experiential learning, which is recorded in some way, (2) personal } \\
\text { experience (Cleary, Whittaker, Gallacher, Merrill, Jokinen, \& Carette, 2002) } \\
\text { - learning from their past achievements and experiences, usually from } \\
\text { experience unrelated to an academic context (Fahy, Perrin, \& Ferrer, 1999; } \\
\text { Harvey, 2004) } \\
\text { - existing competencies (Nyatanga, Forman, \& Fox, 1998) } \\
\text { - learning for which no certification has been awarded by an educational } \\
\text { institution or another education/training provider (Konrad, 2001) } \\
\text { - non-formal and informal learning (Wilcox \& Brown, 2002) }\end{array}$ \\
\hline $\begin{array}{l}\text { Accreditation of Prior } \\
\text { Certificated Learning } \\
\text { (APCL) }\end{array}$ & $\begin{array}{l}\text { - learning for which certification has been awarded by an educational institution } \\
\text { or another education/training provider (Konrad, 2001) }\end{array}$ \\
\hline Prior learning & - learning acquired outside known public ec \\
\hline $\begin{array}{l}\text { Assessment \& } \\
\text { Recognition (PLAR) }\end{array}$ & $\begin{array}{l}\text { 2003; The Calibre Group of Companies, 2003) } \\
\text { - skills, knowledge and attitudes through a variety of formal and informal } \\
\text { channels (Bélanger \& Mount, 1998) } \\
\text { - competences required in non-formal learning. (Scholten \& Teuwsen, 2002) }\end{array}$ \\
\hline $\begin{array}{l}\text { Recognition of Prior } \\
\text { learning' (RPL) }\end{array}$ & $\begin{array}{l}\text { - any combination of formal or informal training and education, work experience } \\
\text { or general life experience (Bateman et al., 2003; Harvey, 2004; Thomson, } \\
\text { Saunders, \& Foyster, 2001) }\end{array}$ \\
\hline
\end{tabular}




\begin{tabular}{|c|c|}
\hline Term / abbreviation & $\begin{array}{l}\text { Type of learning } \\
\text { - prior learning and experience (Cantwell \& Scevak, 2004; Donoghue et al., }\end{array}$ \\
\hline & $\begin{array}{l}\text { 2002) } \\
\text { - learning arising from their experiences in a variety of contexts outside } \\
\text { educational institutions (Cretchley \& Castle, 2001) } \\
\text { - learning that occurred before the assessor became involved (New Zealand } \\
\text { Qualification Authority, 2001) } \\
\text { - non-credentialed or informal learning (Taylor \& Clemans, 2000; Wheelahan et } \\
\text { al. , 2002) }\end{array}$ \\
\hline Validation & $\begin{array}{l}\text { - competences already gained through earlier experiences, even if these are } \\
\text { not formally documented (Andersson \& Fejes, 2005) } \\
\text { - the entire scope of knowledge and experience irrespective of the context } \\
\text { where the learning originally took place (non-formal and informal learning) } \\
\text { (Colardyn \& Bjørnavold, 2004; Pouget \& Osborne, 2004) } \\
\text { - non-formal learning, which takes place outside formal education and training } \\
\text { institutions (Bjørnavold, 2001) }\end{array}$ \\
\hline $\begin{array}{l}\text { Valuation of Prior } \\
\text { learning (VPL) }\end{array}$ & $\begin{array}{l}\text { - what has been learned in every possible learning environment (Duvekot, } \\
\text { 2005) }\end{array}$ \\
\hline Erkenning & $\begin{array}{l}\text { - informal learning (Dutch Ministry of Economic Affairs, 2000) } \\
\text { - competencies of an individual (Onderwijsraad [Dutch Educational Council], }\end{array}$ \\
\hline Competenties & $\begin{array}{l}\text { 2003; Scheltema, 2002; Vanhoren, 2002) } \\
\text { - competences acquired elsewhere, outside of regular education (Thomas et } \\
\text { al., 2000) }\end{array}$ \\
\hline
\end{tabular}


Quality of Procedures to Assess Prior learning 31

Table 3.

The Characteristics of APL (columns) Related to the Quality Criteria for Assessment (rows)

Type of Structure Possible Benefits Assessment Support Time

learning outcomes methods for the investment

Fitness for purpose •

Transparency

Acceptability

Reproducibility of

decisions

Comparability

Fairness

Cognitive

complexity

Fitness for self-

assessment

Meaningfulness

Authenticity

Educational

consequences

Costs and

efficiency 